\title{
ANALISIS MASLAHAH MURSALAHTERHADAP PENDAPAT PENGHULU KUA WONOCOLO SURABAYA TENTANG NILAI MAHAR
}

\author{
Imam Nur Syamsuddiin, Lailatul Widyawati, M Ainur Rosidi, M \\ Dhiyaulhaq, Nova Riskiyana Setiyahani \\ Universitas Islam Negeri Sunan Ampel Surabaya \\ Jl. A. Yani 117 Surabaya. Email: imamnur1999@gmail.com
}

\begin{abstract}
This paper is the result of research using field research methods to answer two questions, that is: how is the view of the head of KUA Wonocolo in carrying out the registration of marriages with low value for dowry and how is the analysis of the maslahah mursalah in figh and KHI on the view of the head of KUAWonocolo in carrying out the registration of marriage which is nominally small. Data collection in this research was taken through interviews and documentation and then the data were analyzed using editing and organizing techniques. The opinion of the head of the KUA regarding the rejection of submissions for dowry with a small penalty occurred at KUA Wonocolo, Surabaya. According to the KUA Wonocolo, the dowry price can be an indicator of marriage readiness for the bride and groom. the opinion of the head of KUA regarding the dowry boundaries used by the head of KUAWonocolo is based on the concepts of fiqh and KHI, which then the authors analyze with the concept of maslabah mursalah. The results of this research conclude that the aim of the head of KUA Wonocolo argues that he rejects the submission of dowry with a small penalty because, it is considered not to show the seriousness of the prospective husband to foster a bousehold with his future wife and the opinion of the head of KUAWonocolo is in accordance with the concept of maslahah mursalah.
\end{abstract}

Keyword: KUA Wonocolo, opinion, dowry value, maslahah mursalah

Abstrak: Tulisan ini merupakan hasil penelitian menggunakan metode penelitian lapangan (field research) untuk menjawab dua pertanyaan, yaitu: bagaimana pandangan penghulu KUA Wonocolo dalam melakukan pencatatan perkawinan yang nilai maharnya bernilai kecil serta bagaimana analisis maslabah mursalab dalam fiqh dan KHI terhadap pandangan penghulu KUA Wonocolo dalam melakukan pencatatan perkawinan yang nominal maharnya kecil. Pengumpulan data dalam penelitian ini diambil melalui wawancara dan dokumentasi kemudian data dianalisis menggunakan teknik editing dan organizing. Pendapat penghulu KUA mengenai penolakan pengajuan mahar yang bernominal kecil terjadi di KUA Wonocolo Surabaya. Menurut penghulu KUA Wonocolo, nilai mahar dapat menjadi indikator kesiapan menikah bagi kedua calon mempelai. pendapat penghulu KUA tentang batasan mahar untuk

AL-HUKAMA

The Indonesian Journal of Islamic Family Law

Volume 09, Nomor 02, Desember 2019; ISSN:2089-7480 
melakukan perkawinan, pertimbangan tersebut digunakan KUA Wonocolo dalam melakukan penetapan batasan mahar dengan didasari konsep fiqh maupun $\mathrm{KHI}$, yang kemudian penulis analisis dengan konsep maslahah mursalah. Hasil dari penelitian ini menyimpulkan bahwa tujuan penghulu KUA berpendapat menolak pengajuan mahar yang bernominal kecil karena, dianggap tidak menunjukkan keseriusan calon suami untuk membina rumah tangga dengan calon istrinya dan pendapat KUA Wonocolo tersebut telah sesuai dengan konsep maslahah mursalah.

Kata kunci: KUA Wonocolo, pendapat, nilai mahar, maslahah mursalah.

\section{Pendahuluan}

Dalam sebuah perkawinan terdapat beberapa syarat dan rukun yang harus dipenuhi. Dari sekian banyak rukun dan syarat sahnya sebuah perkawinan salah satunya adalah mahar. Mengenai mahar sebagian ulama berbeda pendapat. Sebagian dari mereka berpendapat bahwa mahar yang diberikan sesuai dengan kesepakatan kedua pengantin, pendapat ini dikemukakan oleh Sufyan Ats-Tsauri, Syafi'I, Ahmad dan Ishak. Namun, Imam Malik berpendapat pemberian mahar tidak boleh kurang dari seperempat dinar. Penduduk kuffah berpendapat bahwa mahar tidak boleh kurang dari sepuluh dinar dan mahar wajib menurut al-Qur'an beserta sunnah.1

Mengenai status hukum mahar, para ulama juga berbeda pendapat, menurut Imam Malik mahar merupakan rukun rukun dari perkawinan, hal ini karena mahar disebutkan dalam akad dan termasuk dalam bagian akad itu sendiri. Sedangkan menurut jumhur, mahar merupakan syarat sahnya perkawinan, oleh karena itu tidak boleh diadakan persetujuan untuk meniadakan mahar.2

Pentingnya mahar dalam perkawinan merupakan jalan yang menjadikan keharmonisan seorang istri menjadi ridha dan senang menerima suaminya sebagai pemilik atas dirinya. Pentingnya mahar juga menjadi salah satu hal yang memperkuat hubungan dan menumbuhkan tali kasih sayang dan saling mencintai, serta sebagai usaha memperhatikan dan menghargai kedudukan.

Mahar bernominal kecil menuai pro kontra, sebab mahar dianggap masyarakat memiliki keterkaitan dengan harga diri seorang

1 M. Abdul Ghofar, Fiqh Wanita, (Jakarta: Pustaka Al-Kautsar, 2007), 412

2 Darmawan, Eksistensi Mahar dan Walimah, (Surabaya: Srikandi, 2007), 9 
wanita yang hendak dinikahi. Sehingga besar kecilnya mahar dapat menentukan kesejahteraan keluaraga di masa sekarang. Observasi pertama yang dilakukan di KUA Wonocolo pada bulan September 2019, peneliti menemukan fenomena ditemukannya pengajuan mahar yang bernominal kecil di KUA Wonocolo, pengajuan tersebut bernilai Rp. 50.000. menurut pengakuan KUA Wonocolo mahar yang bernominal kecil tersebut kurang relevan dengan pendapatan rata-rata orang yang hendak menikah saat ini. Jumlah ini bernominal sangat kecil untuk ukuran masa kini, sebab saat ini ekonomi di daerah sini sudah cukup baik dan terus bertumbuh. Bahkan jumlah tersebut tidak sebanding lurus dengan harga melakukan perkawinan sah secara agama dan Negara sesuai peraturan perundang-undangan apabila ijab qabulnya dilakukan di luar KUA.

Peneliti kemudian menemuakan fenomena bahwa mahar bernominal kecil memiliki tantangan tersendiri dalam melakukan pengajuan per kawinana di KUA Wonocolo. Dalam adat kebiasaan masyarakat di daerah ini, mahar dianggap memiliki hubungan dengan harga diri seorang wanita yang hendak dinikahi. Karena itu pegawai KUA Wonocolo tidak jarang menolak mahar bernominalkecil dengan memberikan masukan dan nasihat kepada calon pengantin yang hendak mengajukan mahar bernominal kecil untuk menaikkan nominal mahar.

Penelitian ini merupakan penelitian lapangan (field research) yang mengkaji pendapat KUA Wonocolo Surabaya. Penelitian ini dilakukan untuk menjawab dua pertanyaan, yaitu: bagaimana pandangan penghulu KUA Wonocolo dalam melakukan pencatatan perkawinan yang nilai maharnya bernilai kecil serta bagaimana analisis maslabah mursalah dalam fiqh dan KHI terhadap pandangan penghulu KUA Wonocolo dalam melakukan pencatatan perkawinan yang nominal maharnya kecil. Data untuk menjawab kedua pertanyaan tersebut digali dengan metode wawancara. Untuk mendapatkan data, wawancara dilakukan kepada penghulu KUA Wonocolo yang juga menjabat sebagai ketua KUA Wonocolo Surabaya. Data yang telah terkumpul melalui proses wawancara kemudian dikumpulkan untuk dianalisis menggunakan teknik editing dan organizing. Setelah analisis data dilakukan, penulis kemudian 
melihat data dengan perspektif konsep maslahah mursalah dalam fiqh dan maslabah mursalab dalam KHI kemudian penulis bandingkan keduanya.

\section{Pencatatan Perkawinan dengan Pengajuan Mahar Bernominal Kecil di KUA Wonocolo Surabaya}

Sebelum menjelaskan tentang pencatatan perkawinan dengan pengajuan mahar bernominal kecil di KUA Wonocolo Surabaya, perlu penulis jelaskan bahwa penghulu KUA merupakan orang yang berperan penting dalam proses pernikahan calon mempelai. Sebab, penghulu KUA lah yang akan menfasilitasi calon mempelai untuk melangsungkan perkawinan. Penghulu KUA yang penulis wawancara adalah penghulu KUA yang juga menjabat sebagai Ketua KUA Wonocolo.

Di dalam pekerjaannya sebagai penghulu KUA, ditemukan cukup banyak kasus pengajuan mahar bernilai kecil. Pengajuan mahar bernominal kecil tidak jarang ditolak oleh penghulu KUA karena dinilai tidak mencerminkan keseriusan kedua mempelai untuk membangun rumah tangga.

Penghulu KUA Wonocolo berpendapat bahwa, Mahar adalah pemberian dari suami kepada istri atas ganti dari kehormatan seorang istri, maka mahar memiliki keterkaitan erat dengan kehormatan seorang wanita, oleh sebab itu, mahar yang benominal kecil kurang disetujui pihak Penghulu Kantor Urusan Agama (KUA) Kecamatan Wonocolo Surabaya karena nominal yang kecil dianggap tidak menunjukkan keseriusan calon suami untuk membina rumah tangga dengan calon istrinya. Menurut penghulu KUA Wonocolo, pengajuan mahar bernominal rendah terkadang menggambarkan keragu-raguan niat orang yang hendak menikah3.

Pengajuan mahar bernominal kecil yang pernah ditemukan oleh penghulu KUA Wonocolo di KUA wonocolo Surabaya disebutkan sebesar Rp 50.000,00. Pengajuan mahar dengan nominal tersebut dianggap Penghulu KUA kurang etis untuk diberikan sebagai mahar kepada calon mempelai wanita4.

3 Zainul Hadi, Wawancara, KUA Wonocolo Surabaya, 25 September 2019

4 Ibid. 
Mahar bernominal Rp 50.000,00 tersebut dinilai memiliki jumlah yang minim di lingkungan KUA Wonocolo yang berada di wilayah Surabaya sebagai Ibu Kota Provinsi Jawa Timur. Apabila dibandingkan dengan Upah Minimum Kerja (UMK) Kota Surabaya sebesar Rp 3.871.052,61 mahar tersebut dinilai sangat rendah. Pengajuan mahar Rp 50.000,00 tersebut merupakan jumlah dengan nominal yang rendah untuk ukuran waktu saat ini dengan pertumbuhan ekonomi Kota Surabaya yang cenderung baik dan merata. Jumlah uang Rp 50.000,00 di Surabaya sudah dianggap tidak terlalu berharga untuk ukuran mahar seorang wanita.

Jumlah tersebut pun tidak berbanding lurus dengan besarnya biaya yang dikeluarkan apabila melakukan akad nikah di luar KUA yang berdasarkan Peraturan Pemerintah No. 48 Tahun 2014 tentang perubahan atas Peraturan Pemerintah No. 47 tahun 2004 tentang Tarif Atas Jenis Penerimaan Negara Bukan Pajak Yang Berlaku Pada Departemen Agama, dikenakan biaya sebesar Rp 600.000,00. Disamping itu pula, nominal pengajuan mahar sebesar RP 50.000,00 juga tidak sebanding dengan biaya yang dikeluarkan saat melakukan resepsi pernikahan. Apalagi jika menilik pemahaman fiqh masyarakat yang menganggap mahar adalah pemberian wajib untuk menunjukkan penghormatan seorang suami kepada istrinya.

Penghulu KUA Wonocolo menegaskan, apabila pihak calon laki-laki adalah seseorang dengan kekayaan melimpah lalu kemudian memberi mahar dengan nominal yang sangat kecil tentu hal tersebut tidaklah maslahat dan tidak adil. Penghulu KUA Wonocolo menuturkan bahwa apabila ada pengajuan mahar yang bernominal kecil seperti pengajuan mahar sebesar Rp 50.000,00 yang ditemukan di KUA Wonocolo atau jumlah nominal kecil lainnya, akan dilakukan upaya pendekatan oleh penghulu KUA Wonocolo. Pendekatan yang dilakukan disini yaitu dengan mengedukasi masyarakat yang hendak melakukan pengajuan mahar bernominal kecil dengan memberi penjelasan mengenai makna mahar, fungsi mahar, manfaat mahar dan penjelasan lain seputar mahar5.

Penghulu KUA Wonocolo berpendapat bahwa setelah dilakukan edukasi mengenai mahar kepada calon pengantin yang

5 Ibid. 
hendak menikah, calon pengantin umumnya berubah pikiran dan memilih untuk menaikkan nilai nominal mahar mereka dibanding saat ia belum mendapatkan edukasi tentang pentingnya mahar. Pengajuan mahar bernominal kecil sebetulnya terjadi akibat ketidak tahuan calon pasangan terhadap esensi, kegunaan dan manfaat adanya mahar dalam kaitannya membangun rumah tangga.

Faktor pendorong yang mempengaruhi pendapat penghulu KUA Wonocolo Surabaya kurang setuju dengan pengajuan mahar bernominal kecil adalah karena faktor kemaslahatan bagi rumah tangga yang akan dibangun kelak, selain itu karena perempuan patut dihargai dengan baik dengan cara memberikan mahar yang terbaik untuknya sebagai bentuk penghormatan suami kepada istrinya.

Mahar bernominal kecil seperti Rp 50.000,00 tidak terlalu berharga untuk ukuran waktu saat ini, Penghulu KUA Wonocolo berpendapat bahwa mahar Rp 50.000,00 itu bahkan memiliki nilai lebih rendah dibanding harga saat melakukan seks di Surabaya dengan seorang wanita Pekerja Seks Komersial (PSK) yang biasa dibandrol Rp 350.000,00 sekali melakukan hubungan badan6.

Tidak bermaksud menyamakan mahar dengan perbuatan jual beli hanya saja menurut penghulu KUA Wonocolo, tidaklah pantas apabila nilai perempuan yang baik-baik diberi mahar sebagai sebuah penghormatan kepadanya dengan nominal nilai yang sangat rendah bila dibandingkan dengan perbuatan dosa zina dengan seorang Pekerja Seks Komersial (PSK) sekali melakukan hubungan badan.

Oleh sebab itu, Penghulu KUA Wonocolo menganggap mahar harus memiliki nilai nominal yang berharga sesuai dengan keadaan perekonomian yang ada di Kota Surabaya atau jika dilihat dari ratarata pengajuan mahar yang ditemukan di KUA Wonocolo Surabaya berjumlah kurang lebih sebesar Rp 500.000,00. Meskipun begitu, mahar harus disesuaikan dengan kesanggupan calon suami namun harus tetap mengingat bahwa nilai mahar sebagai wujud dari pengganti kehormatan atau kehalalan calon istri. Selain sebagai penghalalan atau kehormatan seorang istri, mahar juga dilihat sebagai tolak ukur tingkat kesejahteraan keluarga setelah dilakukannya akad nikah. Secara tidak langsung hal demikian telah

6 Ibid. 
menjadi pola pemikiran yang berkembang di masyarakat Kota Surabaya, bahwa calon istri atau perempuan dinilai dirinya dari pemberian mahar atas suaminya.

Penghulu KUA Wonocolo berpendapat mengenai mahar yang bernilai kecil akan di persulit dalam melakukan pencatatan perkawinan di KUA Wonocolo Surabaya sebab hal tersebut dapat menjadi indikator bahwa terjadi ketidak siapan melakukan perkawinan. Mahar dinilai bernominal rendah apabila nilainya jika di bandingkan dengan kebutuhan ataupun tuntutan di masa sekarang memiliki nilai yang sangat tidak sesuai. Oleh sebab itu, hal tersebut memiliki keselarasan dengan maslahat yang hendak di ambil7.

\section{Konsep Maslahah Mursalah}

Maslahah mursalah menurut bahasa terdiridari dua kata, yaitu maslahah dan mursalah. Kata maslahah (مصلحة) berasal dari kata ( (صلح) yang berarti sesuatu yang mendatangkan kebaikan. Sedangkan kata mursalah (مرسلة) berasal dari kata (ارسل) yang berarti diutus, dikirim atau dipergunakan. Perpaduan dua kata menjadi maslahah mursalah yang berarti prinsip kemaslahatan (kebaikan) yang dipergunakan menetapkan suatu hukum Islam. Juga dapat berarti, suatu perbuatan yang mengandung nilai baik (bermanfaat). 8

Dari segi pandangan syara' maslahah mursalah dibedakan menjadi 3 , yang diantaranya yaitu:

1. Al-Maslahah Mu'tabarah, yaitu maslabah yang secara tegas diakui syariat dan telah ditetapkan ketentuan-ketentuan hukum untuk merealisasikannya. Misalnya diperintahkan berjihad untuk memelihara agama dari rongrongan musuhnya, diwajibkan hukum qishash untuk menjaga kelestarian jiwa, ancaman hukuman atas peminum khamar untuk memelihara akal, ancaman hukuman zina untuk memelihara kehormatan dan keturunan, serta ancaman hukuman mencuri untuk menjaga harta9

2. Al-Maslahah Al-Mulghah, yaitu sesuatu yang dianggap palsu karena kenyataannya bertentangan dengan ketentuan syari'at.

7 Ibid.

8 Amir Syarifuddin, Ushul Fiqh Jilid 2, (Jakarta: Bina Ilmu, 2010), 142.

9 Rafsan Mulky, Ushul Fiqh, (Bandung: Pustaka Setia, 2009), 149. 
Misalnya ada anggapan bahwa menyamakan pembagian warisan antara anak laki-laki dan anak wanita adalah Maslahah. Akan tetapi kesimpulan seperti itu bertentangan dengan ketentuan syari'at, yaitu ayat 11 surat An-Nisa yang menegaskan bahwa pembagian anak laki-laki dua kali pembagian anak perempuan.

3. Al-Maslabah Al-Mursalah, dan maslabah macam inilah yang dimaksud dalam pembahasan ini, yang pengertiannya adalah seperti dalam definisi yang disebutkan diatas. Maslahah macam ini terdapat dalam masalah-masalah mu'amalah yang tidak ada ketegasan hukumnya dan tidak pula ada bandingannya dalam AlQuran dan Sunnah untuk dapat dilakukan analogi. Contohnya peraturan lalu lintas dengan segala rambu-rambunya. Peraturan seperti itu tidak ada dalil khusus yang mengaturnya, baik dalam Al-Quran maupun Sunnah Rasulullah. Namun, peraturan seperti itu sejalan dengan tujuan syari'at yaitu dalam hal ini adalah untuk memelihara jiwa dan harta.

Dari segi kekuatannya sebagai hujjah dalam menetapkan hukum, Maslahah ada tiga macam, yaitu Maslahah dharuriyah, Maslahab hajiyah, Maslabah tahsiniyab10

1. Maslahab dharuriyah adalah segala hal yang menjadi sendi eksistensi kehidupan manusia, harus ada demi kemaslahatan mereka. Bila sendi itu tidak ada atau tidak terpelihara secara baik kehidupan manusia akan kacau, kemaslahatannya tidak terwujud, baik didunia maupun di akhirat.

2. Maslahah hajizah adalah semua bentuk perbuatan dan tidakan yang tidak terkait dengan dasar yang lain (yang ada pada maslahah dharuriyah) yang dibutuhkan oleh masyarakat tetap juga terwujud, tetapi dapat terhindarkan kesulitan dan menghilangkan kesempitan.

3. Maslahab tabsiniyah adalah tindakan atau sifat-sifat yang pada prinsipnya berhubungan dengan makarimul akhlak serta memelihara keutamaan dalam bidang ibadah, adat dan muamalah.

Maslahah mursalah bisa dijadikan sebagai dalil dengan syarat, sebagai berikut: 
1. Maslahah mursalah tersebut harus maslabah yang hakiki, bukan sekedar maslahah yang diduga atau diasumsikan. Maksudnya adalah untuk membuktikan bahwa pembentukan hukum pada suatu kasus mendatangkan kemanfaatan dan menolak bahaya.

2. Kemaslahatan tersebut harus kemaslahatan umum, bukan kemaslahatan pribadi atau kemaslahatan khusus. Maksudnya ialah untuk membuktikan bahwa pembentukan hukum pada suatu kasus adalah mendatangkan manfaat bagi mayoritas umat manusia atau menolak bahaya dari mereka bukan untuk kemaslahatan individu dan sejumlah peroarangan yang merupakan minoritas dari mereka.11

3. Kemaslahatan tersebut sesuai dengan maqashid syariah dan tidak bertentangan dengan dalil syara'. Oleh karena itu tidak sah mengakui kemaslahatan yang menurut persamaan antara laki-laki dan perempuan dalam hal pembagian warisan, karena hal itu bertentangan dengan nash Al-Qur'an.

\section{Mahar Menurut KHI dan Fikih Munakahat}

Mahar dalam pasal 1 huruf (d) KHI adalah "pemberian dari calon mempelai pria kepada mempelai wanita, baik dalam berbentuk barang, uang, jasa yang tidak bertentangan dengan hukum islam"12. Pemberian mahar sesuai dengan KHI adalah kewajiban yang harus ditunaikan, dengan mahar yang jumlah, bentuk dan jenisnya disepakati oleh kedua belah pihak. Ketentuan mahar yang diberikan oleh sang suami berdasarkan atas asas kesederhanaan dan kemudahan yang dianjurkan oleh agama islam.

Pasal 30 KHI menyatakan bahwa, "calon mempelai pria wajib membayar mahar kepada calon mempelai wanita yang jumlah, bentuk dan jenisnya disepakati oleh kedua belah pihak". Selain itu, pasal $31 \mathrm{KHI}$ menyatakan bahwa, "penentuan mahar berdasarkan asas kesederhanaan dan kemudahan yang dianjurkan oleh ajaran islam".

Pengertian mahar menurut fiqh adalah harta yang berhak didapatkan oleh seorang istri yang harus diberikan oleh sang suami baik karena akad maupun persetubuhan haqiqi. Pengarang kitab $\mathrm{Al}$ -

11 Ibid., 146

12 Tim Permata Press, Kompilasi Hukum Islam KHI 
'Inayah 'Ala Hamisyi Al-Fathi mendefinisikan mahar sebagai harta yang harus dikeluarkan oleh suami dalam akad pernikahan sebagai imbalan persetubuhan, baik dalam penentuan ataupun dalam akad.13

Madhzab Hanafi mendefinisikan mahar sebagai sesuatu yang didapatkan seorang perempuan akibat akad pernikahan ataupun persetubuhan. Adapun madhzab Maliki mendefinisikan mahar sebagai sesuatu yang diberikan kepada seorang istri sebagai imbalan persetubuhan dengannya. Sedangkan menurut madhzab Syafi'i mendefinisikan mahar sebagai sesuatu yang di wajibkan sebab perkawinan ataupun persetubuhan.

Menurut madhzab Hambali medefinisikan mahar sebagai pengganti dalam akad pernikahan, baik mahar ditentukan dalam akad, ataupun ditetapkan setelahnya dengan kerelaan dari kedua belah pihak. Sebagaimana dijelaskan dalam Q.S an-Nisa ayat 4: "berikanlah maskawin-maskawin kepada wanita-wanita sebagai pemberian dengan penuh kerelaan. Lalu jika mereka dengan senang hati menyerahkan untuk kamu sebagian darinya, maka makanlah pemberian itu! Enak lagi baik akibatnya".14

Mahar berasal dari bahasa Arab, al-Mahru.15 Ini mengacu pada beberapa kata yang mengandung arti sama yakni mahar, niblah, faridhah, hiba', ujr, 'uqar, dan alaiq. Semua kata tersebut mengandung pengertian pemberian wajib sebagai imbalan dari sesuatu yang diterima.

Menurut Raghib Isfahani dalam kitabnya "Mufradat Gharib AlQur'an" dikutip dari buku karangan Darmawan yang berjudul Eksistensi Mahar dan Walimab" menjelaskan alasan kata Shadaqah ditulis dengan kalimat Shaduqah adalah karena ia merupakan tanda keikhlasan rohani. Sedangkan kalimat Niblab mempunyai arti kesukarelaan yang secara spontan menjelaskan tidak mengandung maksud lain kecuali untuk pemberian hadiah.16

13 Wahbah az-Zuhaily, Fiqh Islam wa Adilatubu, (Jakarta: Gema Insani, 2011)

14 Al-Qur'an dan Terjemahan, Departemen Agama RI (Bandung: CV Diponegoro, 2010)

15 Moh Makmum, Keluarga Sakinah: Keluarga Nirkekerasan, (Yogyakarta: LKiS Pelangi Aksara, 2015), 38

16 Darmawan, Eksistensi Mahar dan Walimah., 7 
Sedangkan mengenai standar yang paling rendah bagi mahar, para fuqaha saling berbeda pendapat. Menurut Mazhab Hanafi standar mahar paling rendah adalah 10 dirham. Menurut Mazhab Maliki standar mahar yang paling rendah adalah seperempat dinar atau tiga dirham perak murni. Sedangkan menurut Mazhab Syafi'i dan Hambali berpendapat tidak ada batasan terendah bagi mahar.17

\section{Analisis perbandingan Maslahah Mursalah menurut KHI dan Fiqh tentang Pendapat KUA Wonocolo Surabaya mengenai Mahar Bernominal Kecil}

Kompilasi Hukum Islam terbentuk adanya kebutuhan sejak adanya peradilan agama yang mempunyai kewenangan untuk menyelesaikan masalah-masalah hukum keluarga, sehingga diperlukan adanya hukum tertulis karena kitab yang digunakan hakim sangatlah beragam.18 Kompilasi Hukum Islam merupakan perpaduan dari permaslahan yang diambil dari pemikiran-pemikiran para para Imam Mazhab yang dijadikan satu untuk menjadi dasar hukum yang digunakan di Indonesia. Setiap pembentukan suatu peraturan hukum harus didasari landasan filosofi, sosiologis, dan psikologis untuk memperjelas cita-cita dan tujuan ditetapkan sebuah hukum. Hal ini juga berlaku dalam tercetusnya pasal 30 Kompilasi Hukum Islam.

1. Landasan Filosofi

Penghulu KUA Wonocolo berpendapat bahwa, Mahar adalah pemberian dari suami kepada istri atas ganti dari kehormatan seorang istri, maka mahar memiliki keterkaitan erat dengan kehormatan seorang wanita, oleh sebab itu, mahar yang bernominal kecil kurang disetujui pihak Penghulu Kantor Urusan Agama (KUA) Kecamatan Wonocolo Surabaya karena nominal yang kecil dianggap tidak menunjukkan keseriusan calon suami untuk membina rumah tangga dengan calon istrinya.

Ketentuan pasal 30 Kompilasi Hukum Islam ini mempunyai landasan filosofi demi melindungi hak pribadi yang seharusnya didapatkan oleh istri dimana perkawinan itu terjadi, agar

17 Wahbah az-Zuhaily, Figh Islam wa Adilatubu., 235-236

18 Warkum Sumitro, Perkembangan Hukum Islam di Tengah Kebidupan Sosial Politik di Indonesia, (Malang: Bayumedia Publishing, 2005), 178. 
kehormatan seorang wanita tetap terjaga karena merasa dihormati dengan adanya pemberian mahar atau uang hadiah ini sebagai kewajiban suami yang menikahi dan juga sebagai bukti sang suami memiliki kesanggupan untuk menafkahi.

Keberadaan ketentuan pasal $30 \mathrm{KHI}$ tersebut sekaligus menjadi landasan bagi pihak wanita untuk menuntut pihak lakilaki agar bersedia bertanggung jawab dan memberikan mahar ketika melangsungkan perkawinan. Di dalam KHI, mahar ini diatur di dalam pasal 30 sampai pasal 3819, di dalam pasal 30 dinyatakan: "Calon mempelai pria wajib membayar mahar kepada calon mempelai wanita yang jumlah, bentuk dan jenisnya disepakati oleh kedua belah pihak"

Dari pasal diatas menjelaskan bahwa calon mempelai lakilaki yang akan melakukan perkawinan dengan seoran wanita wajib membayar mahar yang besar jumlahnya ditentukan oleh kesepakatan antara calon mempelai laki-laki dan mempelai perempuan.

Pasal yang juga sangat penting diperhatikan adalah terdapat didalam pasal 31 yang berbunyi: "Penentuan mahar berdasarkan atas asas kesederhanaan dan kemudahan yang dianjurkan oleh ajaran Islam.

Kemudian dalam pasal 31 diatas menjelaskan bahwa pemberian mahar yang diberikan oleh calon mempelai laki-laki harus berdasarkan asas kesederhanaan dan kemudahan. Pasal ini memiliki makna tersirat agar mahar seharusnya tidak menjadi penghalang pasangan dalam melakukan perkawinan karena perihal pihak calon istri meminta syarat nominal mahar yang berada diluar kemampuan pihak calon suami. Meskipun sederhana, hendaknya calon mempelai pria dalam menentukan mahar juga memperhatikan asas kepatutan dan nilai yang layak, tidak terlalu rendah.

2. Landasan Sosiologis

Di Indonesia sebelumnya tidak terdapat hukum tertulis perihal kewajiban pemberian mahar sebelum ditetapkannya KHI (Kompilasi Hukum Islam). Sering kali mahar dilalaikan, namun

19 Tim Permata Press, Kompilasi Hukum Islam (KHI), 9-10. 
untuk daerah atau suku tertentu seperti Minangkabau atau Suku Banjar yang mewajibkan pemberian mahar dengan beberapa ketentuan minimal tentu saja secara adat tidak melalaikannya namun untuk daerah delta seperti Sidoarjo ataupun Surabaya, seringkali pembahasan mahar dilalaikan asal rukun perkawinan terpenuhi.20

Khoirudin Nasution menemukan bahwa istilah mahar secara sosiologis merupakan produk sosial pra Islam yang berfungsi sebagai uang ganti (pembayaran) pemeliharaan kepada orang tua wanita yang akan dinikahi.21

Menurut Anderson, sejak jaman pra-Islam (Arab jahiliyah) telah ada berbagai macam corak perkawinan patrilineal dan patrilokal, matrilineal dan matrilokal, hingga perkawinan kontemporer untuk sekedar bersenang-senang (perkawinan mut'ah). Bentuk perkawinan terhormat di masa itu yaitu perkawinan pratrilinel dimana pengantin pria membayar sejumlah uang (mahar) kepada atau calon pengantin wanitanya.22

Maka dengan penegakan hukum melalui adanya KHI (Kompilasi Hukum Islam), masyarakat Indonesia terutama Surabaya diharapkan menjalankan perkawinan yang terhormat, karena itulah, mahar seharusnya sesuai dengan kemampuan penafkahan oleh suami, bukan hanya sekedar pemberian dengan landasan kerelaan yang semena-mena semata. Setidaknya begitulah maksud dari Penghulu KUA Wonocolo dalam mengambil tindakan dengan menolak menikahkan jika mahar yang dimohonkan tidak sepadan.

Pendapat KUA yang mengatakan Rp 50.000,00 merupakan mahar yang kurang layak, tidak disebutkan dalam KHI karena KHI hanya menyebutkan asas kesederhanan. Meskipun demikian Pendapat KUA Wonocolo tersebut tidak menyalahi pasal tersebut, karena kondisi kota Surabaya di lingkungan KUA Wonocolo yang berada di wilayah Surabaya sebagai Ibu Kota Provinsi Jawa Timur.

20 Zainul Hadi, Wawancara, KUA Wonocolo Surabaya, 25 September 2019

21 Khoirudin Nasution, Persoalan Mahar dan Perkawinan : Studi Konvensional dan Kontemporer, dalam hermenia, No.2 Vol.1 Juli-Desember 2002, 275.

22 John Anderson, Hukum Islam di Dunia Modern, terj. Machun Husein, (Surabaya: Amarpress, 1990), 48. 
Apabila dibandingkan dengan Upah Minimum Kerja (UMK) Kota Surabaya sebesar Rp 3.871.052,61 mahar tersebut dinilai sangat rendah. Pengajuan mahar Rp 50.000,00 tersebut merupakan jumlah dengan nominal yang rendah untuk ukuran waktu saat ini dengan pertumbuhan ekonomi Kota Surabaya yang cenderung baik dan merata.

Di dalam KHI, mahar diberikan kepada wanita dengan asas kesederhanaan dan kemudahan serta mahar diatur dalam KHI agar mahar merupakan hasil diskusi atau kesepakatan atas jumlah nominal yang dikeluarkan antara pihak calon suami dan pihak calon istri.

Maka apabila dilihat dari pendapat KUA, asas kesederhanaan dan kemudahan yang terdapat di dalam KHI, walaupun menyebut sederhana, hendaknya calon mempelai pria dalam menentukan mahar juga memperhatikan asas kepatutan dan nilai yang layak, tidak terlalu rendah.

Menilik ketentuan pasal $30 \mathrm{KHI}$ terdapat porsi dari pihak istri agar turut andil dalam penentuan jumlah mahar. Hal tersebut diharapkan agar kehormatan seorang wanita tetap terjaga karena merasa dihormati dengan adanya pemberian mahar oleh pihak suami.

Tindakan KUA Wonocolo Surabaya dalam mengedukasi pasangan menurut penulis adalah hal yang tepat dan tidak menyalahi aturan manapun. Mengingat menurut KUA Wonocolo setelah terjadi edukasi terjadi pasangan akhirnya mengajukan pengajuan mahar yang bernominal cukup tinggi. Alasan atas pengajuan mahar bernominal kecil sebelumnya diketahui bahwa karena ketidak tahuan makna mahar di dalam pernikahan sehingga menyepelekan mahar bukan karena ketidak mampuan pihak suami dalam membayar mahar. Pengajuan mahar yang ditingkatkan tidak membuat pasangan merasa dipersulit sehingga tidak menghilangkan asas kemudahan dan kesederhanaan dalam pasal $31 \mathrm{KHI}$.

Di dalam figh, mahar diterangkan bahwa Pemberian mahar menurut kebijakan pegawai KUA Wonocolo, merupakan sebuah penemuan hukum baru. Hal ini karena dalam islam ketentuan mahar ulama' berbeda pendapat dalam penetapan batas mahar. 
Di dalam hadits Rasulullah terdapat sedikit bagian hadits yang menyatakan bahwa sebaik baik mahar itu adalah خَيْرُ الصََّدَاقِ أَيْسَرُه yang berarti bahwa sebaik baik mahar adalah yang paling mudah.23

Hal ini tentunya didasari dengan Kata aysar yang berarti paling mudah. Tetapi terdapat banyak orang memahami hadis ini adalah yang paling murah. Ini adalah pemahaman yang salah, karena yang dimaksud aysar (mudah) itu bukan murah, kemudahan itu dilihat dari kemampuan dan kemudahan dalam mendapatkannya. Bukan yang murah harganya. Mengenai pemahaman diatas bahwa sebaik-baik mahar itu yang mudah bagi suami dan itu dilihat dari kemampuan, bukan murahnya mahar. Seperti contoh apabila seorang laki-laki yang memiliki kekayaan 1 Milyar, maka mahar yang baik adalah yang mudah bagi laki-laki, misal 200 juta itu mudah dan mampu dilakukan bagi laki-laki tersebut, maka 200 juta itu sebaik-baik mahar. Bukan berarti sebaik-baik mahar itu hanya seperangkat alat sholat yang hanya memiliki harga 100 ribu, tetapi pada kenyataannya kekayaan laki-laki tersebut mencapai milyaran. Maka sebaik-baik mahar tersebut adalah yang paling mudah, dan kemudahan tersebut harus sesuai dengan kemampuan yang dimiliki laki-laki.

Mahar di dalam fiqh juga harus didasari oleh kesepakatan kedua belah pihak mengingat dari QS. An-Nisa ayat 4, yaitu:

berikanlah maskawin-maskawin kepada wanita-wanita sebagai pemberian dengan penub kerelaan. Lalu jik a mereka dengan senang bati menyerabkan untuk kamu sebagian darinya, maka makanlah pemberian itu! Enak. lagi baik akibatnya24

Di dalam fiqh, Menurut Mazhab Hambali mahar adalah pengganti dalam akad pernikahan, baik mahar ditentukan dalam akad, ataupun ditetapkan setelahnya dengan kerelaan dari kedua belah pihak.

Hal tersebut dapat dilihat bahwa perempuan diberi porsi dan peran dalam penentuan pengajuan mahar. Hal tersebut tersebut terdapat kemaslahatan agar wanita merasa dihormati dengan adanya pemberian mahar oleh pihak suami.

23 Ibid., 28.

24 Al-Qur'an dan Terjemahan, Departemen Agama RI (Bandung: CV Diponegoro, 2010) 
Antara KHI dan fiqh menurut penulis memiliki makna yang senada dan memiliki kemaslahatan yang sama. penulis mempresentasikan sudut pandang tersebut dengan dasar teori maslahah mursalah. Mengingat mahar sendiri merupakan suatu bentuk penghormatan dan bentuk keseriusan maka sangatlah dianggap tidak pantas jika mahar yang akan diberikan bernilai kecil. Titik dari maslabahnya Antara lain:

1. Menumbuhkan rasa keseriusan dan tidak menganggap remeh sebuah pernikahan.

2. Dapat menjunjung tinggi martabat perempuan dikarenakan perkembangan zaman itu sendiri yang membutuhkan perubahan hukum tersebut.

3. Meminimalisir dampak daripada mahar kecil itu sendiri yang akan menimbulkan faham bahwah menikah itu murah.

Ditinjau dari segi Maqashid Shari'ah, yang menurut Imam Ghazali Maqashid Shariah merupakan suatu yang menjaga tujuan agama bukan hanya untuk menarik sebuah kemanfaatan, tujuan agama adalah terpeliharanya 5 perkara yang terdiri:25

1. Menjaga Agama

2. Menjaga Jiwa

3. Menjaga Akal

4. Menjaga Keturunan, dan

5. Menjaga Harta

Menjaga Agama merupakan tujuan Maqashid Shariah yang pokok, melihat agama islam merupakan sebuah agama yang lebih menjaga martabat umat dalam hidup. Pemberian mahar ditinjau dari segi pemeliharaan agama adalah suatu bentuk penghargaan yang diberikan al-Qur'an untuk lebih menjaga martabat seorang wanita, karena pada zaman Jahiliyyah seorang wanita disitu kaum wanita tidak dihargai sehingga wanita dianggap hal yang rendah. Dalam hal inilah peran pemeliharaan seorang wanita melalui mahar dengan tujuan untuk menghargai seorang wanita. Sedangkan pendapat KUA mengenai pembatasan nominal mahar tersebut jika dilihat melalui pemeliharaan ini merupakan upaya untuk menghargai wanita (calon istri). sebagai contoh sangatlah tidak pantas apabila nilai

25 Moh Khasan, "Kedudukan Maqashid al-Shari'ah dalam Pembaharuan Hukum Islam”, Dimas, No. 2, Volume 8, Tahun 2008, 307 
perempuan yang baik-baik diberi mahar sebagai sebuah bentuk penghormatan kepadanya dengan nominal nilai yang sangat rendah bila dibandingkan dengan perbuatan dosa zina dengan seorang Pekerja Seks Komersial (PSK) sekali melakukan hubungan badan.

Pemberian mahar dilihat dari tujuan pemeliharaan jiwa.26 Menurut pendapat Pegawai KUA tersebut merupakan salah satu upaya untuk menghargai martabat seorang wanita. Pemeliharaan jiwa yang dimaksud disini adalah pemeliharaan martabat dari seorang istri dilihat sebagai bentuk penghormatan dari seorang suami kepada istrinya.

\section{Penutup}

Berdasarkan hasil penelitian yang telah dilakukan oleh tim peneliti, maka dapat diambil kesimpulan yang berkaitan dengan Analisis Al-Maslahah Al-Mursalah menurut KHI dan Fiqh tentang Pendapat KUA Wonocolo Surabaya mengenai Mahar Bernominal Kecil di antaranya sebagai berikut:

1. Pihak KUA menolak mahar kecil. Sebab, pihak KUA berpendapat karena nominal yang kecil dianggap tidak menunjukkan keseriusan calon suami untuk membina rumah tangga dengan calon istrinya.

2. Pihak KUA berpendapat tentang batas nominal mahar telah sesuai dengan konsep Maslabah Mursalah, yang bertujuan untuk menghargai martabat seorang wanita, dan sebagai bentuk penghormatan dari seorang suami terhadap istrinya.

\section{Daftar Pustaka}

Al-Qur'an dan Terjemahan, Departemen Agama RI Bandung: CV Diponegoro, 2010

John Anderson., Hukum Islam di Dunia Modern, terj. Machun Husein, Surabaya: Amarpress, 1990

Wahbah az-Zuhaily' Fiqh Islam wa Adilatubu, Jakarta: Gema Insani, 2011.

Darmawan, Eksistensi Mahar dan Walimah, Surabaya: Srikandi, 2007 M. Abdul Ghofar. Fiqh W anita, Jakarta: Pustaka Al-Kautsar, 2007

26 Ibid., 
Moh Khasan. "Kedudukan Maqashid al-Shari'ah dalam Pembaharuan Hukum Islam”, Dimas, No. 2, Volume 8, Tahun 2008.

Moh Makmum. Keluarga Sakinah: Keluarga Nirkekerasan, Yogyakarta: LKi Pelangi Aksara, 2015.

Rafsan Mulky. Ushul Fiqh, Bandung: Pustaka Setia, 2009.

Khoirudin Nasution, Persoalan Mahar dan Perkawinan : Studi Konvensional dan Kontemporer, dalam hermenia, No.2 Vol.1 JuliDesember 2002.

Warkum Sumitro. Perkembangan Hukum Islam di Tengah Kehidupan Sosial Politik di Indonesia, Malang: Bayumedia Publishing, 2005.

Amir Syarifuddin. Ushul Fiqh Jilid 2, Jakarta: Bina Ilmu, 2010.

Tim Permata Press, Kompilasi Hukum Islam KHI

Zainul Hadi, Wawancara, KUA Wonocolo Surabaya, 25 September 2019 